\title{
Curricular influence and perceptions of engineering graduates on socio ethical issues related to Biotechnology
}

\author{
Savithri Bhat ${ }^{1}$ and Rajyalakshmi $\mathbf{M}^{2}$ \\ ${ }^{1,2}$ Department of Biotechnology, BMS College of Engineering \\ Bangalore, India \\ 1mrlbmsce@gmail.com, ${ }^{2}$ hod.bt@bmsce.ac.in
}

Keywords- ethics; Biotechnology; social responsibility; survey; engineering graduates

\section{Introduction}

Twenty first century is acclaimed to be the century of biology. But, the question is whether we are ethically ready? Biotechnology and genetic engineering is all about gene therapy, GMO foods, Norplant's, transplants, stem cell research and so on which are of immense benefit to mankind [1-4]. On the flip side are inhuman experimentations, terror gases, fetal research and human cloning [5-8].

News such as "Pharmaceutical industry used prisoners for testing their drugs as the prisoners were much cheaper than chimpanzees." are disturbing. An experiment conducted on Guatemalans involved intentionally infecting humans with syphilis organism to test effectiveness of penicillin [9].

Young minds need to be tailored for apt decision making and judgment [10,11]. Incorporation of ethics as compulsory course is essential in Biotechnology engineering curriculum [12].

The course content should include case studies as a large part and Socratic Method of instruction will enhance the understanding and practice of ethics.

A student's personal reflection on complicated issues which are intrigued with multiple aspects need to be perceived to get feedback on the instructed 
course. The ability of the student to judge a situation and combat with it will be reflected in surveys consisting of few performance indices. In the existing scenario, the present study is planned to judge the socio ethical responsiveness of the BE-BT graduates with the several performance indices and the results are analyzed and interpreted.

\section{Methodology}

BE Biotechnology syllabi of BMS college of Engineering includes several courses incorporated with guidelines on safety and regulatory aspects pertaining to BT. The table 1 depicts the various courses and their content pertaining to ELSI (Ethical, legal, social Implications ) of BT product and process development and entrepreneurship, apart from bioethics and biosafety as core course offered in higher semesters. The course appraises the students on issues related with regulations in $\mathrm{R} \& \mathrm{D}$, transfer of technology, bio business, human rights, societal acceptance of BT products, etc. Thus students by the end of their course will have comprehensive view on every aspect of ethics and safety. Further, one of the Program Educational Objectives (PEO) set for the BE biotech program was the socio-ethical responsibility of graduates.

Table 1. Course And Their Content Pertaining To Elsi Of Bt Product And Process Development

\begin{tabular}{|l|l|l|}
\hline SI. No & \multicolumn{1}{|c|}{ Course } & \multicolumn{1}{c|}{ Content pertaining to ethics and/or safety } \\
\hline 1 & $\begin{array}{l}\text { Pharmaceutical } \\
\text { BT }\end{array}$ & $\begin{array}{l}\text { Guidelines for new drug development and } \\
\text { release, FDA, European regulation, ICH, } \\
\text { Indian regulation }\end{array}$ \\
\hline 2 & $\begin{array}{l}\text { Management \& } \\
\text { Entrepreneurship }\end{array}$ & $\begin{array}{l}\text { Problems of entrepreneurship, issues related } \\
\text { to women entrepreneur, support and policies } \\
\text { for SSI, effect of WTO, GATT etc }\end{array}$ \\
\hline 3 & $\begin{array}{l}\text { Genetic } \\
\text { Engineering }\end{array}$ & $\begin{array}{l}\text { Ethical issues related to cloning, GM0s, gene } \\
\text { therapy and their and societal acceptance }\end{array}$ \\
\hline 4 & $\begin{array}{l}\text { Animal } \\
\text { Biotechnology }\end{array}$ & $\begin{array}{l}\text { Ethical n legal issues on development of } \\
\text { transgenic animal and IVF in human }\end{array}$ \\
\hline 5 & $\begin{array}{l}\text { Health } \\
\text { Diagnostics }\end{array}$ & $\begin{array}{l}\text { Clinical trials and clinical research } \\
\text { regulations and policies }\end{array}$ \\
\hline 6 & Diary BT & $\begin{array}{l}\text { National and international regulation on food } \\
\text { quality and safety aspects }\end{array}$ \\
\hline
\end{tabular}

To assess socio ethical responsiveness of our graduates, several queries (Table 2) were put to BT alumni via online survey tool (www. monkey survey.com). The number of alumni responded to the queries were $74(\mathrm{~N})$ and the responses collected are graphically represented.
Table2: Queries Of The Survey Conducted On Graduates In Biotechnology Engineering

\begin{tabular}{|c|c|c|}
\hline SI No. & Query & Answer options \\
\hline \multirow[t]{4}{*}{1} & \multirow{4}{*}{$\begin{array}{l}\text { In your opinion, a life } \\
\text { saving drug should be } \\
\text { patented for }\end{array}$} & 5 years \\
\hline & & 10years \\
\hline & & 20 years \\
\hline & & Never \\
\hline \multirow[t]{3}{*}{2} & \multirow{3}{*}{$\begin{array}{l}\text { Cloning of humans and } \\
\text { animals should be }\end{array}$} & Approved \\
\hline & & Approved with restriction \\
\hline & & Disproved \\
\hline \multirow[t]{2}{*}{3} & \multirow[b]{2}{*}{$\begin{array}{l}\text { Attitude of multinationals } \\
\text { not developing drugs for } \\
\text { rare diseases due to high } \\
\text { cost of production and low } \\
\text { returns }\end{array}$} & Favor \\
\hline & & Disfavor \\
\hline \multirow[t]{2}{*}{4} & \multirow{2}{*}{$\begin{array}{l}\text { Have you donated blood } \\
\text { individually or in a blood } \\
\text { donation camp }\end{array}$} & Yes \\
\hline & & $\begin{array}{l}\text { No } \\
\text { Not eligible for various } \\
\text { reasons }\end{array}$ \\
\hline \multirow[t]{2}{*}{5} & \multirow{6}{*}{$\begin{array}{l}\text { Have you offered charity or } \\
\text { fund for social causes } \\
\text { Have you signed or sent } \\
\text { emails towards social } \\
\text { causes involving atrocities } \\
\text { towards women or children }\end{array}$} & Yes \\
\hline & & No \\
\hline \multirow[t]{4}{*}{6} & & Once \\
\hline & & twice \\
\hline & & More than twice \\
\hline & & Never \\
\hline
\end{tabular}

\section{Results and Discussion}

As given in the table six performance indexes were taken for assessing the socio-ethical responsiveness of the graduates. The results were (total of 74 responses) tabulated (Table 3 ) and were graphically represented in Figure 1-6.

\section{Table 3: The Results Obtained From The Survey}

\begin{tabular}{|c|c|c|c|}
\hline $\begin{array}{l}\text { Sl } \\
\text { No. }\end{array}$ & Query & $\begin{array}{l}\text { Answer } \\
\text { options }\end{array}$ & $\begin{array}{l}\text { Responses } \\
\text { in } \\
\text { percentage }\end{array}$ \\
\hline \multirow[t]{4}{*}{1} & \multirow{4}{*}{$\begin{array}{l}\text { In your opinion, a life saving drug } \\
\text { should be patented for }\end{array}$} & 5 years & 35 \\
\hline & & 10years & 22 \\
\hline & & 20 years & 12 \\
\hline & & Never & 35 \\
\hline \multirow[t]{2}{*}{2} & \multirow{2}{*}{$\begin{array}{l}\text { Cloning of humans and animals } \\
\text { should be }\end{array}$} & Approved & 6 \\
\hline & & $\begin{array}{l}\text { Approved } \\
\text { with } \\
\text { restriction } \\
\text { Disproved }\end{array}$ & 59 \\
\hline 3 & $\begin{array}{l}\text { Attitude of multinationals not } \\
\text { developing drugs for rare diseases } \\
\text { due to high cost of production and } \\
\text { low returns }\end{array}$ & $\begin{array}{l}\text { Favor } \\
\text { Disfavor }\end{array}$ & $\begin{array}{l}21 \\
79\end{array}$ \\
\hline \multirow[t]{2}{*}{4} & \multirow{2}{*}{$\begin{array}{l}\text { Have you donated blood individually } \\
\text { or in a blood donation camp }\end{array}$} & Yes & 58 \\
\hline & & $\begin{array}{l}\text { No } \\
\text { Not eligible }\end{array}$ & $\begin{array}{l}22 \\
20\end{array}$ \\
\hline 5 & $\begin{array}{l}\text { Have you offered charity or fund for } \\
\text { social causes }\end{array}$ & $\begin{array}{l}\text { Yes } \\
\text { No }\end{array}$ & $\begin{array}{l}72 \\
28\end{array}$ \\
\hline \multirow[t]{3}{*}{6} & \multirow{3}{*}{$\begin{array}{l}\text { Have you signed or sent emails } \\
\text { towards social causes involving } \\
\text { atrocities towards women or children }\end{array}$} & Once & 28 \\
\hline & & twice & 34 \\
\hline & & $\begin{array}{l}\text { More than } \\
\text { twice } \\
\text { Never }\end{array}$ & $\begin{array}{l}7 \\
31\end{array}$ \\
\hline
\end{tabular}

Querry no 1: "Fig. 1" depicts the alumni responses for their opinion on "whether a lifesaving drug be patented for prolonged years". About 35\% responded 
for the drug to be never patented and another 55\% favored patent for a very short period, i.e 5/ 10 years. Currently a new drug is given 20 years of protection in many countries. Few countries grant additional protection up to 5 years. From the responses obtained it can be inferred that the students are aware of the huge costs involved in drug discovery, clinical trials and approvals. The responses also indicate that the students are aware of the prolonged years and low success rates of a drug development process.

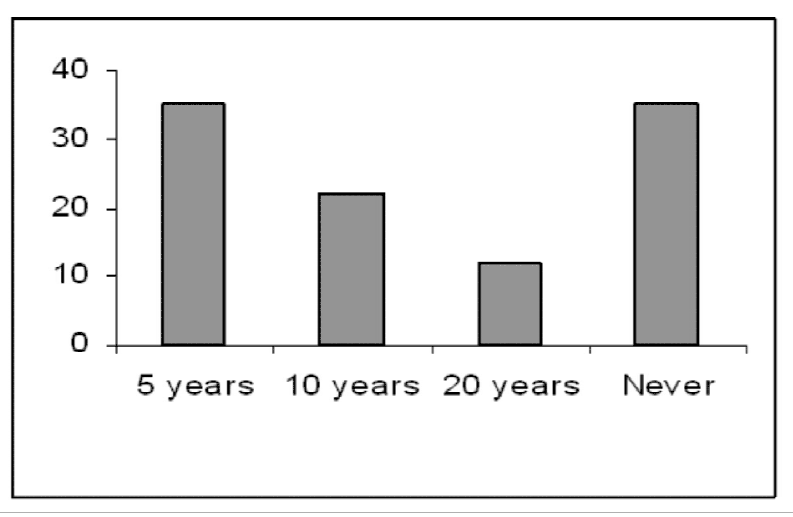

Fig. 1: The alumni responses in percentage for their opinion on "whether a lifesaving drug be patented for prolonged years"

Querry no 2: "Fig. 2" depicts responses of the graduates on the issue of approval for human cloning. The results indicate that $94 \%$ of them disapprove or approve with restriction, indicating their awareness towards the negative implications of human cloning at the same time their awareness on the application of animal cloning in human organ transplantation.

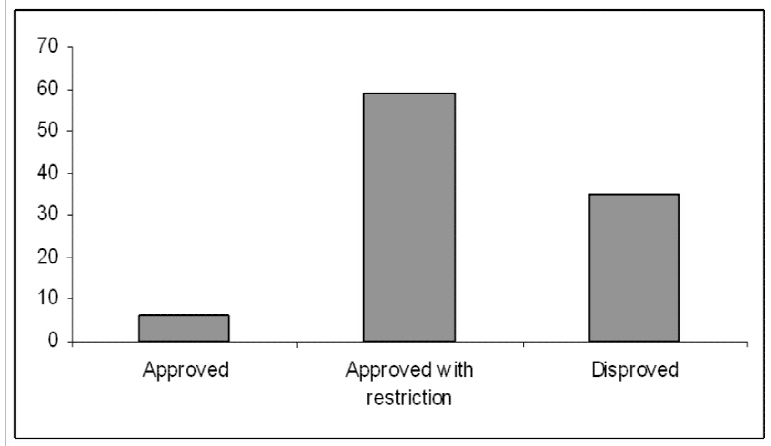

Fig. 2: Alumni responses in percentage on the issue of approval for human cloning

Question No 3: "Fig. 3" depicts the responses on the issue "Attitude of multinationals not developing drugs for rare diseases due to high cost of production and low returns". Majority of the students were in disfavor displaying social concern for the sufferers of rare diseases.

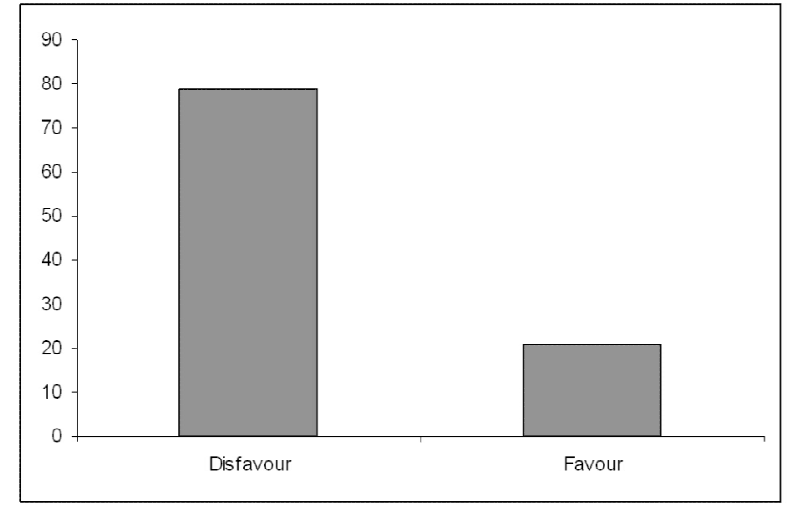

Fig.3: The alumni responses in percentage on the issue of Attitude of multinationals not developing drugs for rare diseases due to high cost of production and low returns

Question No 4: "Fig. 4" depicts the responses on the issue whether they have donated blood individually or in a blood donation camp, about $58 \%$ were affirmative and $22 \%$ were not eligible for the donation. This reflects that the graduates have concern towards the needy patients.

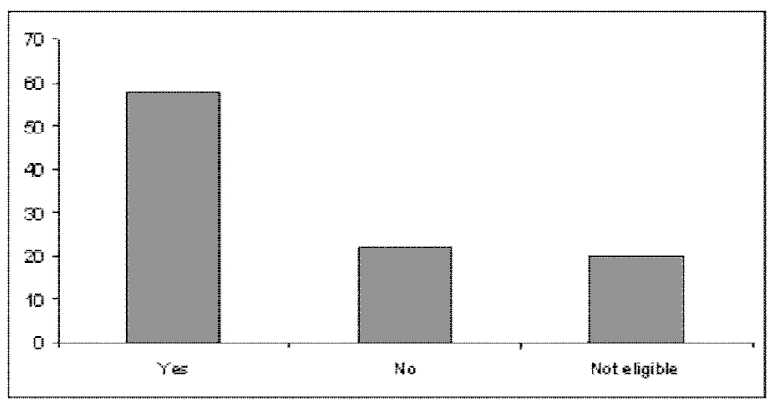

Fig. 4 The alumni responses in percentage on whether or not blood been donated

Question No 5: "Fig. 5" depicts that majority of the graduates donated for a social cause. About $70 \%$ of graduates have donated for social cause.

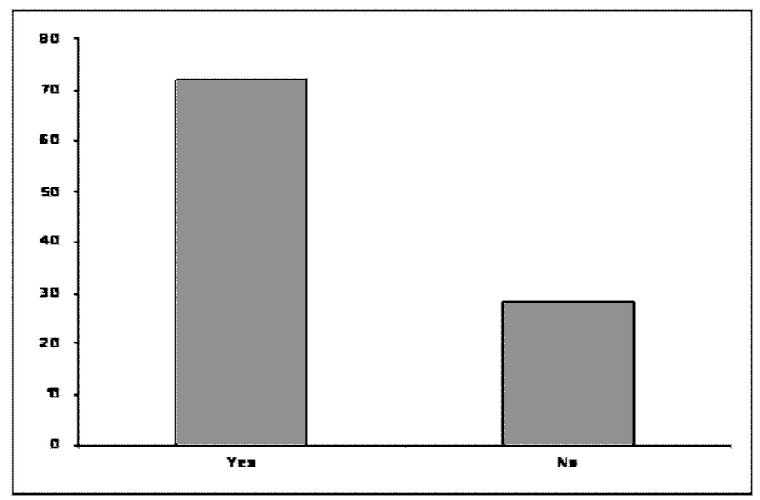

Fig. 5: Alumni responses in percentage on whether or not donation done for social cause 
Question No 6: "Fig. 6" depicts that majority of the graduates have signed for a social cause. More than $65 \%$ of graduates have signed for social cause at least once.

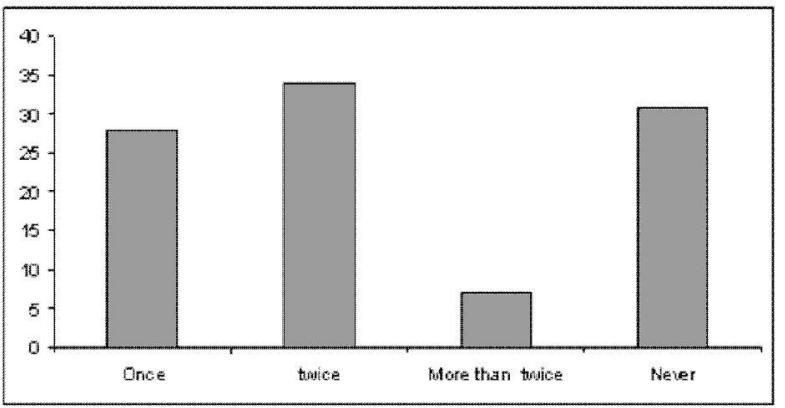

Fig. 6: The alumni responses in percentage on whether or not The graduate ever signed for social cause.

\section{Discussion:}

In a long term study to determine if a Biotech course influenced students' knowledge, acceptance of risk and ethics in biotechnology, survey was conducted at the starting day and ending day of a 13 day- Biotechnology awareness course over ten years. The authors concluded that the responses obtained reflected increase in subject knowledge and better perception on the GMO products, but no compromise in the Ethical attitude [13]. In concurrence, our graduate study results reflected the responsiveness of students to the social issues and acceptance to some extent on the issues involving fetal research and showed no compromise on ethical issues. Studies conducted on students from 11 Western Australian schools on acceptance of BT products derived from organisms, the percentage of acceptance for the use of microorganisms is higher than that of humans and animals [14]. Yet another Europe wide study conducted (2005 \&2010) to assess ' the Levels of approval for embryonic and non-embryonic stem cell research and gene therapy' the authors noted increase in the percentage of people accepting the embryonic stem cell research under strict laws of regulation (from 36 to 51) [15]. In accordance are the responses of our graduates towards animal cloning wherein, 94\% disapprove or approve with restriction.

In conclusion, since many a times social and ethical issues are complex and subjective to a particular scenario, substantial subjectknowledge is advantageous to arrive at an appropriate decision

\section{References}

[1] Macer and R.J. Darryl, "Bioethics: Perceptions of Biotechnology and Policy Implications,"
International Journal of Biotechnology, vol. 3, pp. 116-33, 2001.

[2] Anon, "Time to Grasp the International Perspective on GM Crops," Nature, vol. 399 pp.715, 1999 .

[3] E.F. Einsiedel, "Public Perceptions of Transgenic Animals," Rev. Sci. Tech. Off. Int. Epiz., vol.24(1), pp. 49-157, 2005.

[4] J. Shanahan, D. Scheufele, E. Lee, "Trends: Attitudes about Agricultural Biotechnology and Genetically Modified Organisms," Public Opinion Quarterly, vol. 65(2), pp. 267-81, 2001.

[5] David Finegold and Allison Moser, "Ethical decision-making in bioscience firms," Nature Biotechnology vol. 24, pp. 285 - 290, 2006.

[6] Darryl and R. J. Macer, "Biotechnology in Agriculture: Ethical Aspects and Public Acceptance", Journal: Biotechnology in Agriculture, pp. 661-90, 1997.

[7] C. Dorothy, "Public Perceptions: Surveys of Attitudes Toward Biotechnology", Published Online, 15 OCT 2002.

8. N. DeWitt, "Biologists divided over proposal to create human-mouse embryos", Journal: Nature, pp. 420, 255, 202.

[9] Factact sheet on the 1946-1948 u.s. public health service sexually transmitted diseases (std) inoculation study u.s. public health service sexually transmitted diseases inoculation study of 1946.

[10] W. H. Bingle and P. J. Gaskell, "Science for citizenship for decision making and the social construction of scientific knowledge", Science Education, pp. 78, 185 -201, 1994.

[11] Macer and R. J. Darryl, "Bioethics education for informed citizens across cultures", School Science Review, pp. 86 (315), December 2004.

[12] R. A. Schibeci, "Students, teachers and the impact of biotechnology in the community", Australian Science Teachers' Journal, pp. 46, 27 33, 2000.

[13] S. L. Kitto, L. G. Griffiths and J. D. Pesek, "A long-term study of knowledge, risk, and ethics for students enrolled in an introductory biotechnology course", J ANIM SCI, pp. 81:1348-1353, 2003.

[14] Europeans and Biotechnology," Winds of change?" EUROPEAN COMMISSION, Directorate-General for Research, pp. 55, 2010.

[15] Vaille Dawson and Renato Schibec, "Western Australian high school students attitudes towards biotechnology processes", Journal of Biological Education, pp. 38(1) 7-12, 2003. 